\title{
Pelviureteric Junction Obstruction
}

National Cancer Institute

\section{Source}

National Cancer Institute. Pelviureteric Junction Obstruction. NCI Thesaurus. Code C99007.

A usually cong enital abnormality characterized by the partial obstruction of the junction between the renal pelvis and ureter. It may lead to hydronephrosis. 